\title{
Atlantis
}

Critical Studies in Gender, Culture \& Social Justice

Études critiques sur le genre, la culture, et la justice

\section{Khaki and Emerald Green}

\section{Nancy Taber}

Volume 41, Number 2, 2020

Gender and the Canadian Armed Forces

URI: https://id.erudit.org/iderudit/1076202ar

DOI: https://doi.org/10.7202/1076202ar

See table of contents

Publisher(s)

Mount Saint Vincent University

ISSN

1715-0698 (digital)

Explore this journal

Cite this document

Taber, N. (2020). Khaki and Emerald Green. Atlantis, 41(2), 88-94.

https://doi.org/10.7202/1076202ar

\section{Article abstract}

A short story about a military woman struggling with family, career, and PTSD. Her perspective on her situation shifts when she visits the Canadian Museum of Human Rights with her young son.
All Rights Reserved (C) Nancy Taber, 2020

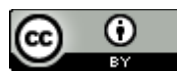

This document is protected by copyright law. Use of the services of Erudit (including reproduction) is subject to its terms and conditions, which can be viewed online.

https://apropos.erudit.org/en/users/policy-on-use/
This article is disseminated and preserved by Érudit.

Érudit is a non-profit inter-university consortium of the Université de Montréal, Université Laval, and the Université du Québec à Montréal. Its mission is to promote and disseminate research.

https://www.erudit.org/en/ 


\section{Special Issue: Gender and the Canadian Armed Forces \\ Literary Work}

\section{Khaki and Emerald Green}

Nancy Taber is a professor at Brock University. Her research explores the ways in which learning, gender, and militarism intersect in daily life, popular culture, museums, educational institutions, and military organizations. She teaches in the areas of critical adult education and sociocultural learning, with a focus on gender and militarism. Her work often draws on her experiences serving in the Canadian military as a Sea King helicopter air navigator. She is a member of the Canadian Association for the Study of Adult Education and a professional member of the Canadian Authors Association. Dr. Taber is a former President of the Canadian Association for the Study of Adult Education and the former Editor-in-Chief of the Canadian Journal for the Study of Adult Education. Dr. Taber is currently focused on fiction-based research intended to disseminate her work to a wider audience.

Abstract: A short story about a military woman struggling with family, career, and PTSD. Her perspective on her situation shifts when she visits the Canadian Museum of Human Rights with her young son.

Keywords: family, fiction, gender, military, museum, PTSD
$\mathbf{R}$ uth burst out the back door of the military supply Repot and gulped the freezing prairie air. She squinted as the bright sun reflected off the snow like a million shimmering knives. The same sun that'd scorched her during her tour in Afghanistan. She closed her eyes to block it out, knelt, and pressed her palms against the icy ground.

Afghanistan had been years ago, after marriage but before kids. Even so, the worst of it flashed back to her on occasion, set off by a sight, smell, or sound. This time, it'd been someone's cologne. Not the same brand, and not strong, but enough of a reminding wisp to choke her, send her racing outside. She forced the clean cold air into her lungs. She pictured her three children-Brianne, Shane, and Timothy-and her husband, Mark, who was posted to Victoria but flew back to visit every chance he could. She just needed to keep her shit together for eleven more months so she could retire with a full pension. Then there would be no more deployments, no more family separation. Only 328 days until she transformed from Army Sergeant to civilian. Tomorrow, only 327. And the next day.... She counted down, picturing the days passing. By the time she got to 250 , her hands stung from the cold enough to distract her from the numbers. She stood. She could manage today. Her shift was almost over. She glanced around, making sure no one had seen her in a crouch, but she was alone. 328 more days.

When she arrived home that afternoon, she kicked through the mess of boots scattered across the front hall. "I'm back," she hollered.

"Hi Mom," Brianne yelled from her bedroom.

"Okay," Shane called from the basement.

“Timothy? You ready?" She removed her beret, jacket, 
and combat boots, stowing them in the hall closet.

"For what?" Timothy said from the den.

"Are you kidding? You begged me to take you to the museum. For your project on workers, remember? Canadian Museum for Human Rights?" Why a gradeone student needed to do research at the museum was anyone's guess, but Timothy had been insistent when he'd heard an interview about the exhibit on the radio.

\section{"That's today?"}

"For the love of god," she mumbled. "And why doesn't anyone ever put away their stuff?"

Timothy raced past her and dashed up the stairs. "Have to get my notebook."

She sighed, strode to her own room, and changed into yoga gear. One of these days she'd actually use it for exercise, but for now its stretchy material forgave the pounds she'd layered on. Her therapist said working out would help manage her stress, but who had time for that? PTSD was the official diagnosis, and though that was probably correct, Ruth tried to push away the "trauma" part of it. That was something that could get her kicked out of the military, if it interfered with her work. Even if the military had caused the trauma. The organization wasn't much for irony. Or weakness. Especially in women.

Her stomach growled. She'd used her lunch break to get Shane's braces removed. The orthodontist bills would've shattered their bank account if it weren't for their work benefits. Small mercies. She reached into her bedside table, grabbed a Mars bar, and gobbled it. As the chocolate melted in her mouth and the sugar buzzed through her, she switched her plain blackframed glasses for the pink ones Mark had given her. He'd wanted her to view the world from a rose-coloured perspective. Impossible, but it made the distance between them-three provinces and $2500 \mathrm{~km}$ —feel just a little bit smaller.
Three years ago, when they were deciding if they'd accept postings to bases in different provinces, they'd argued about the date of her retirement. It was after Sunday dinner; they'd let the kids escape without clearing the dishes so they could talk.

"It's not worth your health," Mark had said as he loaded the dishwasher. "Every day you step onto a military base, another piece of you shrivels. Even after all this time."

"That's an exaggeration," she said. "And they're not robbing me of my pension. I need to finish my twenty years."

"I don't want to be separated from you and the kids."

"And I don't want to be a single mother. It's difficult enough to juggle everything, deal with everything, as it is."

"The kids can't come with me," he said. "I'll be deployed for six months of the year. Your posting is just on base."

What he didn't say was that he'd also seem less dedicated to the military if he was a full-time parent. Welcome to her life. "Yes, Mark, I'm aware."

"If you retire now," he said, "we can all move to Victoria together."

"Then you retire now and move with us to Winnipeg." Ruth slammed a dirty pot onto the counter.

"Why would I do that? You want to get out and I don't." Mark waved the dishtowel in frustration.

"I suppose that settles it, doesn't it?" she said.

"Maybe it would help if you talked to someone about what happened in Afghanistan."

"I do talk. To you. To my therapist."

"That's not what I mean and you know it. Things have 
changed." Mark had reached out to hold her hands. "You said you trust your current supervisor. Tell him about it. And how it was swept under the rug. Or file a report on it to that centre the military created."

"Too little too late." Reporting it now wouldn't erase the pain of being told then that, in the grand scheme of things, what happened to her wasn't important.

Now, she shoved off the memory, adjusted her glasses, and returned to the entryway. There were still boots everywhere, and no sign of Timothy.

“Timothy, we said we'd leave at 5:30." She managed to keep her voice just short of a bellow. She pulled on her bomber jacket.

He bounded down the stairs. "I have thirty seconds."

"If you're not five minutes early..." she said.

"I know, I know, you're late. But according to the real world," he held his Sponge Bob SquarePants watch out, "I still have ten seconds."

"The military is the real world. Just different than the civilian one."

"Will you be different when you retire?"

God, she hoped so. "Bundle up. I'll wait outside." She leaned past him and hollered, "Shane and Brianne, we're going."

The kids called out their good-byes.

"Lasagna's in the fridge. Two minutes in the microwave for each piece should do it," Ruth said.

"Yes!" said Shane. "Cheese, cheese, cheese. No sticky braces."

"Make sure you brush those expensive teeth after dinner," Ruth said.

"I need a permission slip signed for my soccer tourna- ment," Brianne yelled.

"When I get home. And put away your crap." She shook her head. It wasn't their fault every ounce of her patience was eaten away trying to stay calm at work. When the jokes about the military's Operation HONOUR started-Operation HOP-ON-HER some of her colleagues renamed it-Ruth kept her mouth shut. When the survey asking who'd experienced harassment had been circulated to their email accounts, she'd ignored the guffaws, the comments that women couldn't take a joke. It was something she'd dealt with her entire service. Not all the time, of course. There were good people in the military. She'd married one of the best. Still.... She stepped outside and willed her mood to cool with the frosty wind.

Timothy slammed the door of the house a few minutes later. He wore his toque backwards, mittens on the wrong hands, and his brother's boots.

"There's a reason you each have your own cubbies," she said. "To keep your stuff from getting mixed up."

"Did it on purpose. Shane said I couldn't fill his shoes, but I can. Just had to wear extra socks."

She locked the front door as Timothy threw himself onto the snowy front lawn.

"Car," she said. "Now."

Twenty minutes later, they arrived at the museum's parking lot. "Remember the plan?" She'd printed a map of the museum, traced their route to the workers' exhibit, and marked a meeting place.

Timothy yanked a crumpled piece of paper from his pocket. "Yeah, got it. But why do I need it? They have signs at the museum, you know."

"If you're prepared_-" she said.

"You'll never be surprised," he finished. "But surprises are fun." 
"Parties can be fun. Balloons can be fun. Surprises, not so much."

Ruth locked the car and clasped Timothy's hand. The museum's glowing glass structure seemed like a floating cloud, with a tower that spiralled into the night sky. Ruth's eyes focused on the curved entrance as she tugged her son forward.

"Did you know it has one entire kilometre of ramps? I'm gonna run all the way up." He lifted onto his tiptoes. "And all the way down." He bent his knees into a duck walk. "After we can take the elevator to the tower." He straightened into a normal gait.

"We're here for a project, not to explore."

"We can do both."

"Work first, then we'll see."

As they entered the spacious lobby, had their tickets scanned, and hung up their coats, Ruth pointed out the emergency exits. "Don't use them unless there's a fire, attack, or disaster. Meet me at the information desk if we get separated." Her older children had started rolling their eyes whenever she launched into a "safety briefing," as they called it, but Timothy still listened.

“Got it.” He ran ahead.

"Stay close," she called after him.

He slowed his pace to an elongated stride. She caught up at the ramp's closed-in and dimly lit entrance. She stopped and turned. "Is the ramp like this the whole way?" she asked their ticket scanner.

"What do you mean?"

"It's a tunnel."

"It opens up. Takes you from darkness into light. You'll see.”
Timothy turned his face up to her. "Mom? Want to hold my hand?"

"Thanks, hon." She took it and squeezed. "I'm fine. You go on." Timothy, of all her children, was the most sensitive to her moods, but his sweetness both warmed and twisted her in equal measure. It was a reminder that he was affected by what had happened to her, even though he'd been born long after.

Timothy ran forward, dodging other visitors with just enough space so she didn't have to yell at him.

"It's perfectly safe," she muttered as she followed. "Don't be an idiot." After a few twists and turns, the tunnel opened into a large darkened room on the second floor, with several people scattered throughout. There was a long screen that ran the length of the room, playing a film about human rights. On the other side were dozens of blue, orange, and burgundy signs highlighting world-wide historic events.

Timothy approached three glass cases in the middle, labelled Rights on the Job. "Found them."

"Which are you going to choose?"

“'Hidden Hazards Underground.' See the cool helmet?"

She glanced at the case. The exhibit was about uranium miners in Elliott Lake, lackluster safety equipment, and cancer rates. She shivered at a picture of two miners digging into cavern walls. All that rock and dirt. Danger lurking. "It's a hard hat."

Timothy sat on a bench to write in his notebook. "Can you take a picture of me? Make sure you get the case in the background. This is gonna be the best. Bet nobody else thought of coming here."

She snapped a photo. "Tell me when you're done." She turned away, her eyes skittering over the jumbled timeline of events: 1864-1949, Geneva Conventions call for humanitarian treatment of war victims; 1791, Olympe de Gouges publishes Declaration of the Rights 
of Woman and the Female Citizen. A small panel, with a video of a female Major-General discussing the rights of women in the military, grabbed her attention. Equal rights my ass. Maybe on paper. She stabbed at the panel to stop it. No visitor controls. Damn. The background changed to an image of a desert, enveloping her in a memory of heat and dust. Combatants. Body bags. And... memories of that night swirled dangerously close to her.

Timothy tugged on her sleeve. "Mom!”

Ruth shook her head to chase her thoughts away. "Sorry, hon, what?"

"Why didn't you answer me?"

"I was just...watching the film."

"It's over."

"Right. How's the research going?"

"All done."

“Great, let's go."

"Please, can we stay? It's still early. I did my homework. I even cleaned my room after school. Sort of. I think I forgot about my socks. But still. Pleeease."

She bent down and smooshed him in a hug.

"Ugh. Too tight."

She sniffed. "Just a thank-you for cleaning your room."

"Could my reward be the museum instead?"

"For a bit longer." She released him and he dashed off.

"Wowza," he said from around a corner as she rushed to keep up. "You gotta see this."
She turned into a bright corridor and gaped at goldcoloured ramps that shimmered as they criss-crossed the space. Up, up, and up. "It's beautiful."

Timothy pulled on her hand. "Let's race up the ramp."

"No running. You walk quickly and I'll walk slowly. Wait for me before you go around each bend so you stay in sight."

"Okay."

He led and she followed. As she stepped towards the ramp, she passed the Share your Story video booth, where visitors could record stories about their rights that were violated and rights that were defended. She'd read about it when she'd skimmed through the museum's website a few days ago. She felt a fleeting tug of temptation to tell her own story. What happened over a decade ago at Camp Nathan Smith in Afghanistan. She closed her eyes and the memories overtook her.

She had stayed past her regular shift to finish inventory. They were engaged in reconstruction efforts to build fifty schools and she didn't want one little girl to go without an education because she'd messed up a reconstruction order: building materials, chalkboards, textbooks, and pencils. More fulfilling than ordering grenades and bullets. She'd walked into the hot night air as the stars burned brightly above. It was then that her life split into the before and after.

He-she'd never discovered who he was but he'd been wearing a military uniform, she could make out that much-had grabbed her from behind. Her mind had whirled. He forced her into a storage container and slammed her onto the metal floor. Pain shot through her body. By the time she'd gained her breath back, he'd latched the door.

"Keep your mouth shut and I won't hurt you," he'd said.

But that was a lie.

When she'd crawled out of that container as the sun 
rose, she'd shuffled to her superior's office to report the attack. As she'd relayed the barest of humiliating details, his eyes filled with compassion. But then he refused to meet her gaze. "Sgt. Burr," he'd said. "Ruth." He flipped through the security updates on the desk in front of him. "This is a complicated matter. Are you sure you want to go forward with this? What with the recent surge in Taliban activity... we need to stay focused on this war. On defeating these terrorists. And it's not as if you know who it was. It could have been anybody. Probably not even a Canadian.”

That was when her love of the military shattered. Not after that night. But after that morning. She was just one woman, after all. Nothing more than collateral damage. Not worth an investigation. She'd thought about resigning as soon as her tour was over, but resolved to stick it out. Leaving would mean they-her attacker and her supervisor-would win, and she couldn't live with that either.

Timothy's voice pulled her back to the present. "Mom, c'mon."

She glanced at her son and continued past the video booth. Her silence was her choice, had helped her cope, but maybe it was no longer the right choice for her.

They ascended the ramp, switch-backing past the third and fourth floors. She focused on her footsteps, on her breath, and the glee on her son's face that contrasted with the sombre nature of the exhibits. With her own murky thoughts. On the fifth floor, he stopped to catch his breath in front of a row of video panels.

A green skirt in an adjacent exhibit caught Ruth's attention. Not khaki green, like her uniform, but emerald, with light green flowers embroidered at the bottom. At least, it might have been emerald when it was new. It was labelled "Skirt with bullet holes, Uganda, 2005.” She peered closer. No blood. What happened to the woman who wore it? She stepped back to read the name of the exhibit: Ododo Wa: Stories of Girls in War. Her body trembled as she read on. The exhibit was about conjugal slavery. Ugandan girls who'd been abducted by the Lord's Resistance Army. Terrorists. But the panel explained it was the government who'd shot at the girl when she escaped with her newborn baby. The girl was betrayed by the people who were supposed to protect her; was that worse for her, that betrayal, than her abduction?

Timothy selected a tab on the panel in front of him. A women's husky voice, accompanied by an acoustic guitar, sang of a soldier, of any height, any religion, any country, a killer who fights for peace but prolongs war. A universal soldier. Just as her experience, and those of the Ododo Wa women, seemed to be universal. Connected-maybe-but not inevitable. That, she refused to accept.

"What's this one about, Mom?" His little fingers traced the child's drawings that formed the background for the exhibit. Huts, soldiers, weapons. A camp map. She resisted the urge to snatch his hands away.

"I think we should keep going," she said. "Don't you want to see the tower?"

"Are you okay?" he asked.

"Of course." She forced a reassuring smile.

He turned to look at something behind her.

She read the final panel of the Ododo Wa exhibit. Two of the girls - now women-had published memoirs about their years of captivity. There was a photograph of the women smiling. Laughing even. Did telling their story help them heal? She focused on her own reflection in the exhibit's glass. Shoulders slumped, rounded back, lifeless arms.

Timothy's reflection danced around hers to another song he'd started playing, one more lively than the one about a universal soldier. "You sure you're okay?" he asked, pausing mid-dance move to peer up at her.

"Yes," she said. This time she meant it. Maybe the video booth was worth a shot. So she could be the one 
taking care of her son. Not the other way around. She squared her shoulders. Straightened her back. Waggled her fingers. Moved her feet. Dragged herself out of her desert.

She would sit in that booth and free herself of what happened by telling her story. In 328 days.

For now, she'd ascend the tower with her son. 